\title{
Legal status of the honorary consular officers: Theory and practice in Latvia
}

\author{
Janis Grasis \\ Rīga Stradinš̌ University, Faculty of Law, Riga, Latvia
}

\begin{abstract}
Honorary consuls are not professional diplomats, it means, they do not make a living as diplomats. They usually do live and work as well as pay taxes in the country where they operate while they do represent their native country on a voluntary/not-salaried/ basis until their appointments are revoked. Honorary consuls have limited authorization to act and conduct on behalf of their native country; they have the honour to serve their respected country and they are usually selected/appointed by their merits. Legal regime relating to honorary consular officers and consular posts headed by such officers is regulated by Vienna Convention on Consular Relations from 1963. According to the Article 59 of the mentioned convention the receiving State shall take such steps as may be necessary to protect the consular premises of a consular post headed by an honorary consular officer against any intrusion or damage and to prevent any disturbance of the peace of the consular post or impairment of its dignity. Similarly, the receiving State is under a duty to accord to an honorary consular officer such protection as may be required by reason of his official position. If criminal proceedings are instituted against an honorary consular officer, he must appear before the competent authorities. Comparative and analytical research methods are used for this paper. The author of this article proposes to introduce a special number sign for cars of the honorary consuls in Latvia, thereby showing special respect for foreign honorary consuls.
\end{abstract}

Key words: honorary consuls, Vienna Convention, protection of consular premises.

\section{Material and methods}

The aim of the article is to analyze legal norms from the Vienna convention and its practical application in the Republic of Latvia, especially concerning functional immunity of honorary consular officer. The research object of the article is international consular law. The tasks of the research are the following: 1) to make general characteristics of the status of honorary consuls; 2) to analyse court practise in Latvia relating to honorary consuls; 3) to work out suggestions to overcome shortcomings in the practise. Comparative and analytical research methods are used for this paper.

\section{Results}

The status of honorary consuls is rarely discussed in the books on international law. For example, M.Shaw looks at consular privileges and immunities, but honorary consuls are not mentioned at all [1]. A similar situation can also be found in compilation of articles of Oxford University [2]. The status of honorary consuls is analyzed in some articles, for example, in a very good article of K. Stringer [3], as well as by the very recent article by Janis Zelmenis [4]. 
The honorary consul does not receive any remuneration from his sending country and is usually an entrepreneur or public servant who has close links with the country to be represented. It is a serious advantage for a country that chooses honorary consuls to represent its citizens. Thus, very often in countries where it would not be economically beneficial to maintain diplomatic missions or career consuls, honorary consuls are appointed [3].

According to the data available on the home page of the Ministry of Foreign Affairs of the Republic of Latvia, 25 honorary consulates are operating in Latvia [5]. During collection of materials for this article, the author sent e-mails to all honorary consuls in Latvia to the all e-mail addresses indicated on our Ministry's home page. The 3 addresses did not exist; the fact which makes doubts on whether all the honorary consuls listed actually perform their functions. Latvia is also represented by 189 honorary consuls and 13 general consul general abroad (data from August, 2017) [5]. The honorary consul or general consul of the Republic of Latvia shall be a person to whom the Republic of Latvia entrusts the performance of state representative and consular functions in accordance with the 1963 Vienna Convention [6], international customs, consular conventions concluded by the Republic of Latvia and other international treaties in force in the Republic of Latvia, the Diplomatic and Consular Service Law and other regulatory enactments. The honorary consul may be both a citizen of the Republic of Latvia and a foreign state; the honorary consul must have an excellent reputation. The honorary consul is not an official and is not an employee of the Ministry of Foreign Affairs of the Republic of Latvia.

In most European countries, honorary consuls in the particular country in question create professional associations. In Latvia, since January 2015, there has been an association - the Honorary Consular Corps in Latvia, which brings together more than ten of the 25 honorary consuls accredited in Latvia [7].

In accordance with subparagraph 2 of the Article 3 of the Law on Consular Assistance and Consular Services [8], consular functions shall be performed by civil servants and employees of the diplomatic and consular service authorised thereto, as well as by honorary consuls of Latvia authorised thereto. Career consuls shall be paid officials of the State, and honorary consuls shall be appointed by the Minister of Foreign Affairs persons worthy of such office who are not remunerated from State resources. Consular missions led by honorary consulates shall be called honorary consulates. As a remuneration for expenses related to the maintenance of the honorary consulate, the Ministry of Foreign Affairs may leave at the disposal of the honorary consul either a certain part of the consular revenues or all of them. The honorary consul shall perform separate consular functions on the basis of a special mandate from the Minister for Foreign Affairs (State Secretary of the Ministry of Foreign Affairs). This mandate can be very broad-based, similar to that of a career consul, or very narrow-based, symbolic. This is determined by the specific interests of the country and by the agreement of the honorary consul himself; customs law and bilateral consular agreements between states can also play an important role. Honorary consuls generally do not have permission to issue visas or passports; as a rule, the honorary consul cannot perform functions where the use of public authority is required, for example, to carry registers or perform notary functions [9]. As a general rule, honorary consuls have two main tasks:

1) development of economic, scientific and cultural relations between countries (in particular, promoting commerce in both directions),

2) protection of the interests of their sending State and their citizens.

However, the functions of the honorary consul may be extended or reduced as necessary [3]. For example, in accordance with the Article 17 of the Law on Consular Assistance and Consular Services the consular officers abroad and honorary consuls shall perform individual no- 
tary functions in accordance with the Notary Law [10]. Notary deeds drawn up by consular officers and honorary consuls shall constitute the same public credibility and have the same legal consequences as they would if such deeds were drawn up by a sworn notary in Latvia [8].

Without the pursuit of classical consular functions, the institute of honorary consul, in good cooperation with entrepreneurs, has created, creates and will continue to create success stories in business. According to the chairman of the board of the Honorary Consular Corps in Latvia and the honorary consul of Malta in Latvia Janis Zelmenis, hotel "Riga" turned into a five-star hotel thanks to the honorary consul: "Nothing happens in business if you don't know a person. Latvia has a distinguished honorary consul in Armenia. Any businessman who has decided to start in Armenia shall be advised to meet him. This consul has excellent contacts and excellent information on both Latvia and Armenia. Question: what does the honorary consul in Armenia has common with a $€ 50$ million investment in Latvia? Answer: Our honorary consul told one wealthy Armenian he had to buy the shabby hotel "Riga" for $€ 25$ million. The wealthy Armenian trusted to the opinion of honorary consul, bought the hotel, took credit from one of Latvia's commercial banks, carried out the hotel renovation, attracted it to the Kempinsky chain, and now the hotel works as an excellent five-star hotel" [7].

In general, if we compare with diplomatic immunity, the total immunity of honorary consuls and consulates is less, but there is no difference of the immunity performing consular functions. According to the article 59 of the 1963 Vienna Convention on Consular Relations, the receiving State shall take such steps as may be necessary to protect the consular premises of a consular post headed by an honorary consular officer against any intrusion or damage and to prevent any disturbance of the peace of the consular post or impairment of its dignity. The term "Consular premises" is explained in the subsection $\mathrm{j}$ ) of the first part of the article 1 of the 1963 Vienna Convention on Consular Relations, and means "the buildings or parts of buildings and the land ancillary thereto, irrespective of ownership, used exclusively for the purposes of the consular post"; besides "The consular premises shall not be used in any manner incompatible with the exercise of consular functions (Part 2 of the article 55 of the 1963 Vienna Convention on Consular Relations).

There are not too many cases in Latvian case-law regarding honorary consuls, but individual cases are interesting enough. One of these is an administrative case for a domestic dispute between husbands at the Indonesian honorary consulate, where the administrative case was launched against the Indonesian honorary consul in Latvia/pers. B/, which was largely dominated by the question of the immunity of consular premises [11].

According to the information provided by the honorary consul, his spouse/pers. $\mathrm{D} /$ provoked /pers. B/to the dispute on June 10, 2014 at the consular premises/address/-95 of the Indonesian honorary consulate, in which/pers. D/had also declared. After/pers. D/sneered on /pers. B/, he took away the computer which his wife had tried to retrieve. About the circumstances of the dispute/pers. B/explained that/pers. D/ was not very stable after alcohol use; /pers. B/ presumed that she had slipped and slipped into the big marriage bed. No violence was done by /pers. B/, so there is no clear reason for minor bodily injury because the bed has no sharp edges or places to get bruises. They may have been obtained under other circumstances. Also to the police he said that never have pushed/pers. D/. In addition, after the incident, they both slept at night in one bed and there was no fear of doing it for /pers. $\mathrm{D} /$. After this incident there has also been another case in which /pers. D/ tried to provoke a dispute to person /pers. B/, but it failed due to the peaceful action. By /pers. B/. Meanwhile, the testimony of the injured woman differed over the events of the evening of June 10, 2014 at Indonesia's honorary consulate. She told her husband that she wanted to divorce and divide the property because she suspected her husband in adultery since 2008. 
She has obtained this information from the computer; /pers. B/ took his wife's computer and threatened to throw it out of the window. Then he put the computer on the bed and pushed her into the bed as she passed, as a result. /pers. D/ breathed to the tallest end of the bed. The head of /pers. D/ was against the mattress, then/pers. B/gripped it and started choking, then /pers. B/ somewhere gone, according to her opinion, after links to tie her up, as he had done it before. /Pers. D/ had enough time to call her mother, and when he returned to the room, there was a call from her mother, after which /pers. B/ wife had not been more physically affected. The most important aspect of this violent dispute, in which the Indonesian honorary consul and his spouse participated, is whether the premises of honorary consul, for which information can be found on the home page of the Ministry of Foreign Affairs, and in which a country's consulate is officially registered, enjoy consular immunity. This was specifically indicated by defender of /pers. B/ Oscar Galander, stressing that the premises in which a honorary consulate is officially registered, enjoy consular immunity. Criminal Justice Board of Riga Regional Court acknowledged that/pers. B/ as the Indonesian honorary consul, as well as the premises in which he performs the role of honorary consul, do not enjoy consular immunity in respect of the administrative violation to be examined. The Criminal Justice Board took into account a definition from the subsection $\mathrm{j}$ ) of the first part of the article 1 of the 1963 Vienna Convention on Consular Relations that "consular premises" means the buildings or parts of buildings and the land ancillary thereto, irrespective of ownership, used exclusively for the purposes of the consular post; as well as second part of the article 55, which determines that "The consular premises shall not be used in any manner incompatible with the exercise of consular functions. It follows from the files of the case that the apartment by address/address $\mathrm{A} /$ which/pers. B/has designated as consular premises, also is declared place of residence of his wife/pers. D/, which is also their actual place of co-residence. In his explanatory notes of 8 July 2014 /pers. B/ stated that during the conflict the examination works were corrected, and we could presume that the premises were not used solely for the purposes of the consular authority. Article 59 of the 1963 Vienna Convention on Consular Relations provides, hat the receiving State shall take such steps as may be necessary to protect the consular premises of a consular post headed by an honorary consular officer against any intrusion or damage and to prevent any disturbance of the peace of the consular post or impairment of its dignity. In the present case, it was found that the actual actions from/pers. $\mathrm{D} /$ in connection with /pers. B/shall not be recognised as intrusion or damage to the consular premises of the consular post, and that action by /pers. D/ has not resulted in a disturbance of peace or a disturbance of the peace to the consular authority within the meaning of the above article of 1963 Vienna Convention, but in a violent dispute case between /pers. B/ and /pers. $\mathrm{D} /$ in their residence and as a result of this dispute wife has suffered minor bodily harm from /pers. B/. It was concluded that the provisions of Article 59 of the 1963 Vienna Convention on the Protection of Consular Relations are not applicable in this case and therefore also indication of /pers. B/ on the obligation of the state of Latvia to take protective measures of the consular authority from peace disturbances are not justified. The author agrees in general with the court's arguments in this case.

The receiving State is under a duty to accord to an honorary consular officer such protection as may be required by reason of his official position (Article 64 of the 1963 Vienna Convention on Consular Relations). However, it should be taken into account that privileges and immunities provided in the 1963 Vienna Convention shall not be accorded to members of the family of an honorary consular officer or of a consular employee employed at a consular post headed by an honorary consular officer(third part of the Article 58 of the 1963 Vienna Convention).Article 61 of the 1963 Vienna Convention, by analogy with career consuls, prescribes that the consular archives and documents of a consular post headed by an honorary consular officer shall be inviolable at all times and wherever they 
may be, provided that they are kept separate from other papers and documents and, in particular, from the private correspondence of the head of a consular post and of any person working with him, and from the materials, books or documents relating to their profession or trade.

If criminal proceedings are instituted against an honorary consular officer, he must appear before the competent authorities. Nevertheless, the proceedings shall be conducted with the respect due to him by reason of his official position and, except when he is under arrest or detention, in a manner which will hamper the exercise of consular functions as little as possible. When it has become necessary to detain an honorary consular officer, the proceedings against him shall be instituted with the minimum of delay. Also, Article 119 of the Criminal Procedure Law of the Republic of Latvia, which guarantees consular immunity in conformity with international treaties, applies to honorary consuls. The right of a person to consular immunity shall be attested by a certificate issued by the Ministry of Foreign Affairs, in which the privileges and immunities of the relevant person are indicated in accordance with international agreements entered into by the Republic of Latvia. If there is a need to detain an honorary consular officer, proceedings against him should be initiated as soon as possible (Article 63 of the 1963 Vienna Convention). Article 63 of the 1963 Vienna Convention does not provide for the immunity of the honorary consul against administrative infringements, but it should be noted that the honorary consul also enjoys functional immunity in the performance of his duties. In practice it is not so easy to draw the border when a person performs the duties of honorary consul and when he does not enjoy functional immunity. This is well characterised by the following example from Latvian case-law.

On 21 November 2015, R. Gabalis, senior inspector of the local municipal police of Riga, compiled an administrative infringement report - notification No 511249554 (hereinafter initial decision), about the fact, that on 21 November 2015 at 11.25 vehicle Mercedes Benz, with/number/parked outside the building in Riga, Meldru Street 1a, in operation area of traffic sign no. 532 and secondary traffic sign no. 833 without time indication, thus failing to comply with the requirements of the article 4., 307.17 of the Road Traffic Regulations [12] (hereinafter-RTR), thus committing an administrative violation for which responsibility is provided in the part 7 of the article 149.10 of the Latvian Administrative Violations Code [13] (hereinafter - LAVC). Administrative fine of Euro 30,- was imposed by initial decision of an administrative infringement report - notification. Decision was appealed to a higher institution by honorary consul - /pers. A/, later in the Vidzeme suburb court of Riga City, which left the court decision of the first instance unchanged. After the judgment of the Vidzeme suburb court of Riga City /pers. A/ (hereinafter referred to as "the Applicant") lodged an appeal in which the Applicant appealed the judgment in full. The Applicant pointed out that at the time the vehicle was parked there was a municipal police vehicle in front of it, where police officers were present and they saw him parking the vehicle. According to his view, the activities of police officers, i.e. immediately drawing up an administrative infringement report - notification without waiting for exceeding 1 hour, are deemed to be a dishonest or even abusive exercise of powers. It is believed that the time mark of parking was formal because police officers saw the moment when /pers. A/ left the vehicle after parking. The Applicant considered that there was no administrative violation in the particular case, since he was not considered as the honorary consul to be the subject of it. The court shall be deemed not to have provided its assessment and justification for when consular functions are or are not performed, but merely referred to a letter from the State Protocol which cannot provide the court with an analysis of binding legal norms. Moreover, it was noted that Article 5 of the 1963 Vienna Convention lists activities (for example, ascertaining by all lawful means conditions and developments in the commercial, economic, cultural and scientific life of the receiving State, reporting thereon to the Government of the sending State 
and giving information to persons interested) which are considered to be consular functions and cannot be carried out without representative means, and their acquisition is therefore considered to be an integral part of the exercise of consular functions. He has also had no intention of committing an administrative violation, since the vehicle has been parked for 20 minutes and in fact no administrative violation has been committed. The Applicant deems to be absurd the situation when police and court try to divide the time when consular functions are carried out and when not; an opinion of dr. iur. Inese Kalnina was also submitted on the immunity of honorary consuls: under the circumstances, his prosecution for administrative violation should not be accepted, as the honorary consul at the time of the events identified in the particular case was granted consular immunity. Representative of local municipal police of Riga Girts Aleksans explained that he did not agree with the Applicant's claim that he had fulfilled the duties of honorary consul of Malta since the Ministry of Foreign Affairs of the Republic of Latvia has indicated that doing shopping does not constitute an activity to be performed within the consular functions. The Court of Appeal held that, pursuant to the first part of Article 43 of the 1963 Vienna Convention, consular officers and consular employees shall not be amenable to the jurisdiction of the judicial or administrative authorities of the receiving State in respect of acts performed in the exercise of consular functions. Article 5 of the 1963 Vienna Convention provides that consular functions are to promote the development of commercial, economic, cultural and scientific relations between the sending State and the host State and to otherwise promote friendly relations between them in accordance with the provisions of this Convention. It is therefore concluded that consular officials have immunity only at the time when they perform their consular functions directly. The acquisition of means of representation does not constitute a consular function but serves as a means to enable these functions to be performed at a later stage [14]. However, the author of this article does not want to agree with the opinion of the local municipal police of Riga, the Ministry of Foreign Affairs of the Republic of Latvia and the decision of the Riga Regional Court. In this particular case the actual circumstances of the case had to be taken into account: the honorary consul had not parked the car in an unauthorised place, police officers of the local municipal police of Riga saw the honorary consul parking the car, and in fact punished not for being misplaced of the car, but for not having a time indication in the window. As mentioned above, even in criminal cases, the honorary consul must be treated with respect due to his official status; in this particular case, there is an administrative violation. Unfortunately, contrary to diplomats, the vehicle registration rules do not provide for special registration signs for consuls and honorary consuls in Latvia. Informally, honorary consuls are given number signs marks with the letters " $\mathrm{CH}$ ", but the background of the sign is the same as the normal signs, which makes it more difficult to distinguish between such numbers in practice. In many foreign states, special number signs are also given to honorary consuls to make it easier for national law enforcement authorities to identify honorary consuls in their country. For example, the following photograph contains the special car sign of the Latvian honorary consul in the state of Karnataka in India (Fig. 1).

The author of the article considers that special number signs for honorary consul cars should also be introduced in Latvia. As for honorary consuls, it could be left to ' $\mathrm{CH}$ ', and additionally letters indicating the country what they represent, and, like diplomats, at least on a red background.

Among other examples, when Latvia infringes the provisions of the 1963 Vienna Convention, the situation with the Mexican honorary consul in Latvia should be noted. He had to have hard fight to meet in prison with a detained citizen of his country. This means that not all employees of the Latvian Internal Affairs ministry have a clear view of what honorary consuls are dealing with in Latvia [7]. 


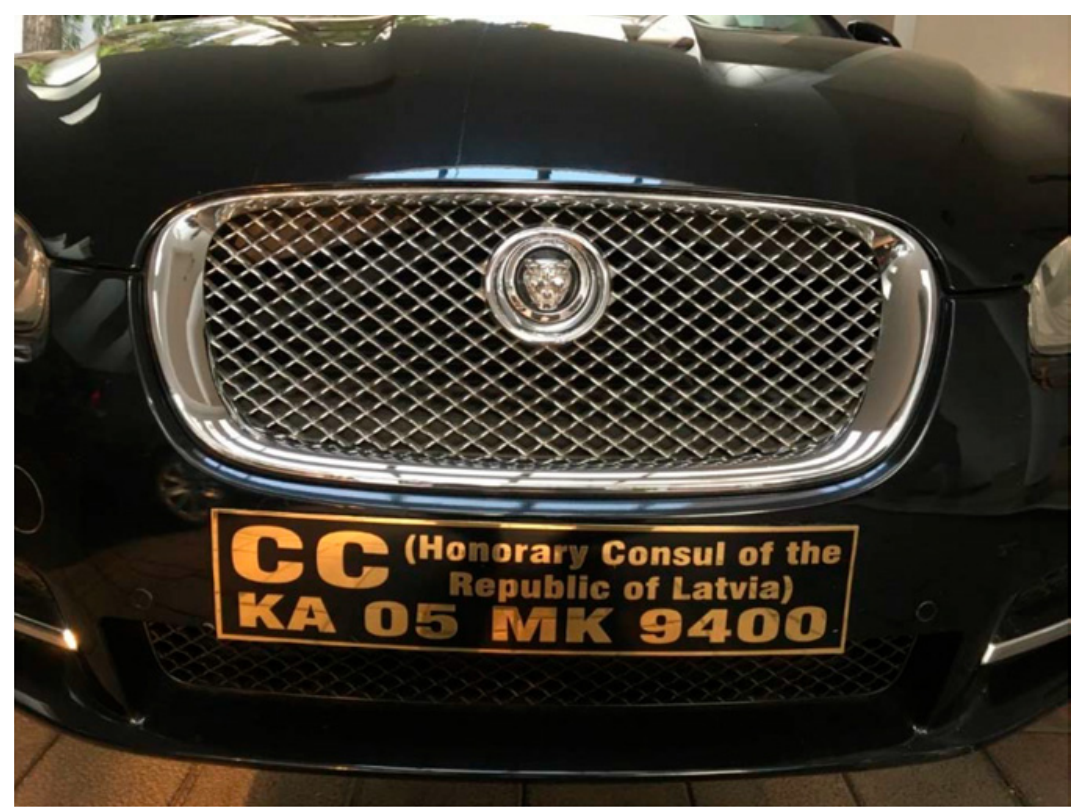

Fig. 1. Special car sign of the Latvian honorary consul in the state of Karnataka in India.

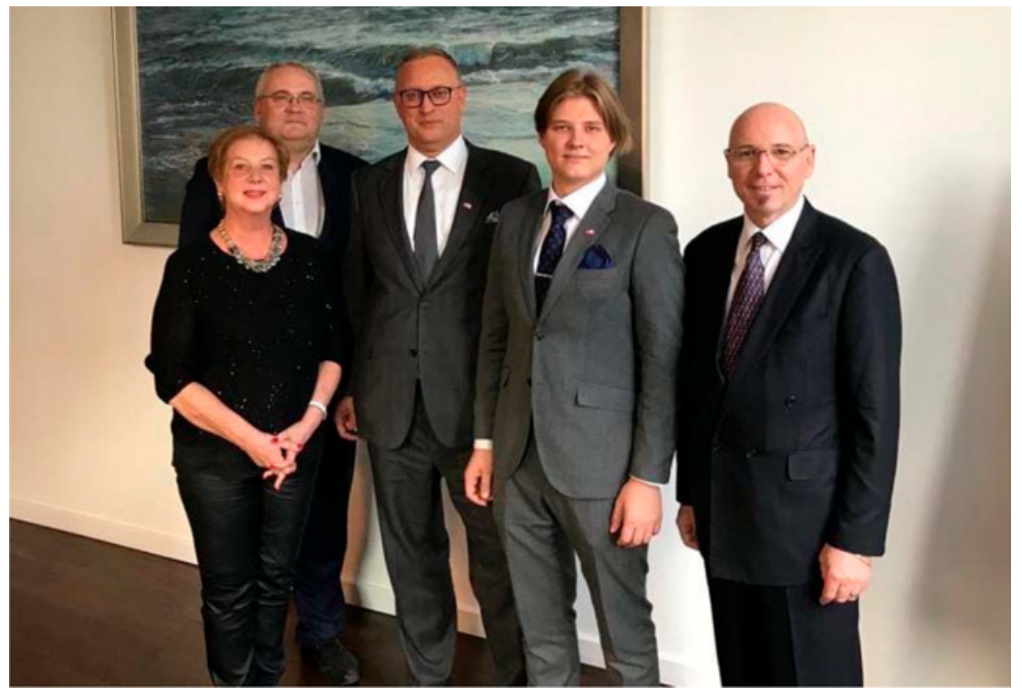

Fig. 2. The author attending meeting of the Association of Honorary Consular Corps in Latvia on October 102018.

Honorary consuls sometimes want to find out how many citizens of the country they represent are in Latvia. The Office of Citizenship and Migration Affairs stated to the honour consul of the Philippines that: "We will not provide you with any data, we have the General Data Protection Regulation [15]". Honorary consul made a remark: "I am not a by-passer, but an honorary consul appointed by the State of the Philippines and accredited in Latvia"... Then the following answer follows: "Okay, we can provide this information, but you have to pay Euro 15 for each person ...'"This creates a confusion for the honorary consul, as he does not 
know whether 300 or 3000 Filipinos are staying in Latvia and how much he will pay [7]. In any case, the honorary consul of a country in Latvia has the right to know the total number of nationals of the country to be represented officially in Latvia, and this is certainly not in contradiction with the General Data Protection Regulation [15].

\section{Conclusions}

It should be acknowledged that the legal status of honorary consuls has not been studied enough in Latvia and in the world. The article shows that there are some practical problems in practical application of the 1963 Vienna Convention on Consular Relations in the Republic of Latvia, especially concerning functional immunity of honorary consular officer. The author of this article proposes to introduce a special number sign for cars of the honorary consuls in Latvia, thereby showing special respect for foreign honorary consuls. In certain cases such step would also help to resolve disagreements between the Latvian authorities and honorary consuls.

I wish to say a warm word and thanks to the Association of Honorary Consular Corps in Latvia and, especially to the honorary consul of Malta in Latvia Janis Zelmenis for supplying practical materials during writing of this article (Fig. 2).

\section{References}

[1] M.N. Shaw, International Law (Fifth edition, Cambridge University Press, 2006), pp. 688-690

[2] International Law, Second edition. Edited by Malcolm. D. Evans (Oxford University Press, 2006), pp. 404-405

[3] K.D. Stringer, Honorary Consuls in an Era of Globalization, Trade, and Investment, Consular Affairs and Diplomacy, Edited by J. Melissen, A.M. Fernández (Leiden: Brill, 2011), p. 63-96

[4] J. Zelmenis, Institute of Honorary Consuls, Moscow J. Internat. Law, No. 2, p. 91-101 (2018)

[5] Ārvalstu pārstāvniecības Latvijā, Electronical resource: https://www.mfa.gov. Iv/ vestniecibas-un-parstavniecibas?type=foreign (Overviewed:19.12.2018)

[6] Vienna Convention on Consular Relations (1963): International agreement. Latvijas Vēstnesis, 2003, July 16

[7] R. Rozenbergs, Goda konsulu institūts tiecas ciešāk sadarboties ar uzņēmējiem. (Neatkarīgā rīta avīze, 2018.gada 28.jūnijā)

[8] Law on Consular Assistance and Consular Services (2018): Law of the Republic of Latvija. Latvijas Vēstnesis, 2018, May 15

[9] Dela M, Legal status of the honorary consul. Wroclaw Review of Law, Administration \& Economics. Der Gryuter open. 4(1), 71 (2014)

[10] Notariate Law: Law of the Republic of Latvia. Latvijas Vēstnesis, 1993, July 9

[11] Administratīvās rajona tiesas 2013.gada 16. decembra spriedums lietā Nr. A420422412. Electronical resource: https://manas.tiesas.lv/eTiesasMvc/ lv/nolemumi (Overviewed: 26.11.2018)

[12] Road Traffic Regulations (2015): Regulations of the Cabinet of Ministers of the Republic of Latvia. Latvijas Vēstnesis, 2015, June 27

[13] Latvian Administrative Violations Code (1984): Law of the Republic of Latvia. Latvijas Padomju Sociālistiskās Republikas Augstākās Padomes un Valdības Ziņotājs, 1984. December 12 
[14] Rīgas apgabaltiesas Krimināllietu tiesas 2016.gada 13. decembra spriedums lietā Nr. 130030416. Electronical resource: https://manas.tiesas.1v/eTiesasMvc/ lv/nolemumi (Overwieved: 31.01.2019)

[15] Regulation (EU) 2016/679 of the European Parliament and of the Council of 27 April 2016 on the protection of natural persons with regard to the processing of personal data and on the free movement of such data, and repealing Directive 95/46/EC (General Data Protection Regulation): EU regulation. Official Journal of the European Union, 2016, April 5 